\title{
Література:
}

1. Votes and Proceedings of the House of Representatives, 1755-1756 (Philadelphia, 1756). P. 19-21. URL: http://franklinpapers.org/franklin/ framedVolumes.jsp?vol=6\& page $=238 \mathrm{a}$.

2. Ziya Aktaş A. Information/Knowledge Society And Europe. Proceedings of World Academy of Science, Engineering and Technology. 2005. Vol. 8. P. 1-6.

3. Petrina S. Technology and (Human) Rights: A Review of Human Rights in the Global Information Society. Workplace. 2010. № 17. P. 147-149.

4. Построение информационного общества - глобальная задача в новом тысячелетии. Декларация принципов. Женева, 2003 год. URL: http://www.itu.int/net/wsis/outcome/ booklet/declaration_Bru.html.

5. Декларация тысячелетия Организации Объединенных Наций, утв. резолюцией 55/2 Генеральной Ассамблеи от 08.09.2000. URL: https://zakon.rada.gov.ua/laws/show/ 995_621\#Text.

6. Communication from the Commission to the European Parliament, the Council and the Committee of the Regions of 22 May 2007 «Towards a general policy on the fight against cyber crime». Brussels, 22.5.2007. $\operatorname{COM}(2007) 267$ final.

DOI https://doi.org/10.30525/978-9934-588-92-1-28

\section{ДЕЦЕНТРАЛІЗАЦІЯ ПУБЛІЧНОЇ ВЛАДИ: ПОНЯТТЯ, ЗМІСТ, ОСНОВНІ ТЕНДЕНЦІї}

\author{
Серьогін В. 0. \\ доктор юридичних наук, професор, \\ професор кафедри конституційного і муніципального права \\ Харківського начіонального університету імені В. Н. Каразіна \\ м. Харків, Украӥна
}

Децентралізація означає передачу повноважень та відповідальності 3 центрального рівня врядування до виборних органів влади на субнаціональному рівні (регіональним органам, муніципалітетам тощо), котрі мають певний ступінь автономії. Децентралізація полягає також у переформатуванні (зміні конфігурації) відносин між центральним урядом та органами влади субнаціонального рівня у бік більш координаційної та стратегічної ролі національних урядів. Вона $€$ 120 
багатовимірним поняттям, оскільки охоплює принаймні три різні, але взаємопов'язані та взаємозалежні виміри: політичний, адміністративний та фіскальний. Залежно від країни суттєво відрізняються форми і ступінь децентралізації, міра вертикальної підзвітності й відповідальності, форми контролю за периферійними органами влади з боку центрального уряду.

Децентралізація, котру іноді називають «тихою» чи «м'якою» революцією, є однією з найважливіших реформ за останні півстоліття. Вона тією чи іншою мірою здійснюється в більшості як розвинутих держав, так і тих, що розвиваються, і має серйозні наслідки через свій складний і системний характер. Участь у процесі децентралізації зачіпає всі сфери суспільного життя, від характеру та якості врядування до національного добробуту й економічного зростання та, у більш загальному плані, до національної безпеки в цілому. На сьогодні можна констатувати, що на початку XXI століття децентралізація стала загальним трендом розвитку демократичного врядування i, як слушно зазначається у звіті ОЕСР за 2019 рік, «питання має полягати не в тому, гарна чи погана децентралізація сама по собі, а в тому, що результати децентралізації - 3 точки зору демократії, ефективності, підзвітності, регіонального й місцевого розвитку - багато в чому залежать від того, як децентралізація спроектована й реалізована» [1].

Фахівці стверджують, що децентралізацію не слід розглядати як панацею від будь-якого типу проблем, з якими може стикнутися країна, так само як не можна розглядати ії як самодостатню мету - скоріше це засіб для досягнення певних цілей [2, с. 87]. Емпіричні компаративні дослідження демонструють, що децентралізація може сприяти зростанню ефективності публічного сектора, активізації інститутів громадянського суспільства, демократизації та політичній стабільності; водночас $є$ й непоодинокі приклади невдач, особливо коли відповідні реформи не були належним чином розроблені й реалізовані, або коли їх багатогранний характер не був добре зрозумілий широким колам громадськості. У сучасному контексті «географії невдоволення» i зростаючого розриву між окремими територіями особливого значення набуває ефективне використання децентралізації для регіонального розвитку, коли окремі територіальні спільноти, котрі відчувають себе обійденими глобалізацією й технологічними змінами, здатні отримати вигоди від сучасних трендів суспільного розвитку. Протягом останнього десятиліття найбільш суттєвої й системної децентралізації зазнали мажоритарні демократії та унітарні держави, тоді як в консенсусних демократіях і федеративних державах децентралізація відбувалася переважно на периферії. 
За даними Всесвітньої обсерваторії субнаціональних державних фінансів та інвестицій ОЕСР-ОММВ у глобальному масштабі субнаціональні видатки складають 9\% ВВП, 24\% державних видатків і $40 \%$ державних інвестицій. У країнах ОЕСР кошти на субнаціональні органи влади теж становлять переважну частину державних видатків, складаючи 16,2\% ВВП, 40,4\% державних видатків і 56,9\% державних інвестицій у 2016 році. При цьому найбільший напрямок видатків складає освіта (25\% видатків на субнаціональному рівні), за нею слідують охорона здроров'я (18\%), публічні послуги (публічна адміністрація), соціальний захист і економіка/транспорт [3].

Замість жорсткого розмежування більша частина повноважень розподіляється між рівнями врядування, і за останні десятиліття ця тенденція лише посилюється. Потреба в такому розподілі повноважень може виникати 3 функціональних причин - як це зазвичай буває між муніципальним i регіональним рівнями 3 питань інфраструктури $\mathrm{i}$ транспорту, охорони довкілля і водних ресурсів, культури і туризму, комунікацій чи економічного розвитку. Вона також може виникнути 3 причин фінансування, наприклад, соціальних послуг. Загалом, між країнами існує велика відмінність у розподілі повноважень на регіональному рівні, тоді як на місцевому рівні вона $є$ значно меншою. I хоча вимір децентралізації є питанням складним і неоднозначним, втім фіскальні й інституційні показники дають підстави констатувати, що загальна тенденція розвитку сучасної державності спрямована саме в бік децентралізації, незважаючи на деякі винятки.

Реформи щодо децентралізації зумовлені широким колом громадсько-політичних, історико-культурних та соціально-економічних причин, які суттєво різняться в тих чи інших країнах. Певні кроки у бік децентралізації в основному були мотивовані прагненням до більш широкого демократичного контролю на місцевому рівні, більшої ефективності в наданні публічних послуг та підзвітності за політику регіонального й місцевого розвитку. Такі мегатенденції, як інформаційна революція, діджиталізація, глобалізація економічної діяльності та урбанізація, також сприяють посиленню ролі субнаціональних органів влади.

Шляхи до децентралізації значно різняться в різних країнах: від підходів «великого вибуху» до поетапних підходів чи «хвиль» реформ. Участь у реформі децентралізації, в кінцевому рахунку, є політичним питанням, i тому його слід розглядати та здійснювати як частину більш широкої стратегії територіального розвитку і більш широких реформ публічного врядування. Децентралізацію слід також розглядати більш комплексно, включаючи взаємодію між державними структурами i 122 
приватними зацікавленими суб'єктами, зокрема громадянами, бізнесструктурами й громадськими об'єднаннями. Реформи децентралізації часто супроводжуються іншими типами багаторівневих реформ територіальної організації публічної влади, особливо реформами місцевого самоврядування й державного управління.

У децентралізації вирізняються ще кілька додаткових тенденцій:

1. Зростання видатків і доходів на субнаціональному рівні. Вони збільшились як у відсотках від ВВП, так і в загальних цифрах. У деяких країнах ця ситуація ускладнилася глобальною фінансовою кризою. Хоча реальна купівельна спроможність субнаціональних органів влади більш обмежена, ніж демонструють фінансові показники, більш повні дані, такі як Індекс регіональних властей та Індекс місцевої автономії, також вказують на підвищення рівня влади регіонів і муніципалітетів за останні десятиліття.

2. Підвищення рівня управління на субнаціональному рівні за рахунок міжмуніципального співробітництва, управління крупними містами та змічнення регіонів (регіоналізація):

- муніципальна роздробленість стимулювала розробку політики, котра заохочувала чи нав'язувала злиття й укрупнення громад, сприяла міжмуніципальному співробітництву як засобу створення економії за рахунок масштабу, підвищення ефективності й економії витрат.

- кількість створених у крупних містах органів управління всіх типів зросла, особливо з 1990-х років; у теперішній час близько двох третин міських агломерацій в країнах ОЕСР мають муніципальні органи управління;

- зростаюча роль регіонів: 381 країни, охопленої Індексом регіональної влади, в 52 спостерігається абсолютне зростання рівня регіональної влади і тільки в 9 спостерігається абсолютне падіння.

Регіоналізація посилює потребу в координації між рівнями врядування й уточненні розподілу повноважень 3 метою уникнення їх дублювання.

3. Посилення асиметричної децентралізації, тобто той факт, щзо органи публічної влади на одному субнаціональному рівні врядування мають різні політичні, адміністративні або фіскальні повноваження.

У той час як у період між 1950-ми і 1970-ми роками асиметричні механізми мали місце в основному на регіональному рівні, теперішня тенденція, схоже, застосовує асиметричну децентралізацію в крупних міських районах. При цьому якщо у федераціях асиметрична децентралізація $\epsilon$ цілком «природною», то в унітарних країнах вона посилюється 3 інших причин. Таким чином, спостерігається більша конвергенція між унітарними й федеративними державами в аспекті 
диференційованого врядування на субнаціональному рівні. Емпіричний досвід демонструє, що одного разу прийняті асиметричні схеми зберігаються на довгостроковій основі.

Паралельно із цими тенденціями, котрі стосуються субнаціональних органів влади, розвивається й роль центральних урядів. Будучи більш стратегічною, ця роль зосереджена на створенні умов для належної координації та узгодження цілей політики, моніторингу ефективності регіонів і муніципалітетів, а також забезпеченні збалансованості розвитку всіх частин національної території шляхом активної політики регіонального розвитку. Реформи щодо децентралізації передбачають перехід від безпосередньої участі в наданні послуг до функції надання можливостей, консультування й допомоги, забезпечення узгодженості та полегшенні роботи субнаціональних органів влади. Це вимагає створення нового потенціалу на рівні центрального уряду, здатного впоратись із цими новими функціями, що охоплюють переважну більшість сфер публічного врядування. Вплив децентралізації на центральний уряд часто недооцінюється, тоді як відсутність повної й адекватної оцінки даного аспекту може завдати шкоди реформам, сповільнюючи чи змінюючи їх.

\section{Література:}

1. OECD (2019). Making Decentralisation Work: A Handbook for Policy-Makers. URL: https://www.oecd.org/cfe/Policy\%20highlights_ decentralisation-Final.pdf.

2. Sills P., Marsden D., Taylor M. Editorial Decentralisation: Current Trends and Issues. Community Development Journal. 1986. Vol. 21. Iss. 2. P. 84-87.

3. OECD/UCLG (2016). Subnational Governments around the world: Structure and finance: a first contribution to the Global Observatory on Local Finances. URL: https://www.uclg.org/sites/default/files/global_ observatory_on_local_finance_0.pdf. 